\title{
Erythrocyte uptake of drugs and its impact on volume of distribution $\left(V_{D}\right)$ determinations
}

Pathirana $\mathrm{W}^{1 *}$, Chandrarathna $\mathrm{D}^{2}$, Wickremasinghe N.N ${ }^{3}$, De Silva P.C ${ }^{3}$, Zoysa $\mathrm{P}^{4}$, Samaranayake N.R ${ }^{3}$, Wijayabandara M.D.J ${ }^{3}$

${ }^{1}$ Department of Pharmacology and Pharmacy, Faculty of Medicine, University of Colombo. ${ }^{2}$ Department of Chemistry, Faculty of Science, University of Colombo. ${ }^{3}$ Bachelor of Pharmacy Program, Faculty of Medical Sciences, University of Sri Jayewardenepura. ${ }^{4}$ Department of Biochemistry and Molecularbiology, Faculty of Medicine, University of Colombo.

Corresponding authors email: pathiranawa@gmail.com*

\begin{abstract}
In most volume of distribution $\left(\mathrm{V}_{\mathrm{D}}\right)$ determinations the drug partitioned in to erythrocytes $\left(\mathrm{C}_{\text {ery }}\right)$ occupying $45 \%$ of blood volume is disregarded. The $V_{D}$ determinations can be erroneous on two accounts. The first is the indiscriminate reference to plasma $\left(\mathrm{C}_{\mathrm{p})}\right.$, whole blood $\left(\mathrm{C}_{\mathrm{b}}\right)$ or serum $\left(\mathrm{C}_{\mathrm{s}}\right)$ concentrations. The second is when $\mathrm{C}_{\text {ery }}$ values are not considered in calculations. Isolated erythrocytes were incubated in plasma water $\left(\mathrm{C}_{\mathrm{pw}}\right)$ represented by physiological saline drug solutions, the $\mathrm{C}_{\mathrm{pw}}, \mathrm{C}_{\mathrm{ery}}$ and $\mathrm{C}_{\mathrm{b}}$ values were experimentally determined in vitro. Aberrations to the $\mathrm{V}_{\mathrm{D}}$ determinations are demonstrated using both theoretically and practically determined values of $\mathrm{C}_{\mathrm{pw}}, \mathrm{C}_{\mathrm{ery}}$ and $\mathrm{C}_{\mathrm{b}}$. Widely varying $V_{D}$ values $125 \mathrm{~L}$ to $2.55 \mathrm{~L}$ resulted when $\mathrm{C}_{\mathrm{p}}$ data alone is used while the values differed marginally from $4.56 \mathrm{~L}$ to $5.53 \mathrm{~L}$ when $\mathrm{C}_{\mathrm{b}}$ values were used for two setting using same amount of drug.
\end{abstract}

Key words: Volume of distribution, Erythrocyte drug concentration $\mathrm{C}_{\text {ery }}$,

\section{Introduction}

The present study highlights the repercussions of indiscriminate use of drug blood concentration $\left(\mathrm{C}_{\mathrm{b}}\right)$, plasma concentration $\left(\mathrm{C}_{\mathrm{p}}\right)$ and serum concentration $\left(\mathrm{C}_{\mathrm{s}}\right)$. A plasma determination is sometimes referred to as blood concentration. The erythrocyte partitioned drug has so far evaded receiving due recognition ${ }^{1}$. This identifies a fourth concentration parameter, which is the erythrocyte concentration of drugs $\left(\mathrm{C}_{\text {ery }}\right)$. This parameter is occasionally mentioned in the literature ${ }^{2}$. The $\mathrm{C}_{\text {ery }}$ values are sometimes over five times higher than the $\mathrm{C}_{\mathrm{p}}$ values ${ }^{3}$.

Isolated erythrocytes were incubated in vitro setting with doxycycline ${ }^{4}$, chloramphenicol, rifampicin, oxytetracycline and chloroquine solutions of known strength. The $\mathrm{C}_{\text {ery }}$ and $\mathrm{C}_{\mathrm{pw}}$ values were determined using standard curves ('Determination of Uptake of Selected Drugs by Red Blood Corpuscles, B. Sc. Pharmacy, Department of Chemistry, 
University of Colombo, 2009 and Influence of Drugs Partitioned in to Red Blood Corpuscles on Volume of Distribution Determinations, University of Sri Jayewardenepura, B. Pharm program 2015).

The results were treated to demonstrate variations in volume of distribution values with and without taking into account $\mathrm{C}_{\mathrm{rbc}}$ values. Similar variations were also demonstrated for situations where $\mathrm{C}_{\mathrm{b}}, \mathrm{C}_{\mathrm{p}}$ or $\mathrm{C}_{\mathrm{s}}$ is used indiscriminately. The volume of distribution studies are understood with the aid of compartment models ${ }^{5}$.

\section{Materials and methods}

Model theoretical $V_{D}$ calculations based on plasma $\left(C_{p}\right)$, serum $\left(C_{s}\right)$ or whole blood $\left(C_{b}\right)$ concentrations:

The symbol $\mathrm{C}_{\mathrm{pw}}$ is for in vitro studies without using blood. The total blood volume of an adult is considered to be $4.5 \mathrm{~L}$. Since $55 \%$ by volume of blood constitute plasma, the volume of plasma approximates $2.5 \mathrm{~L}$.

A $25 \mathrm{mg}$ of a drug $\mathrm{X}$ was administered by IV bolus to a subject resulting in an immediate plasma concentration of $(25 \mathrm{X}$ $1000) /(2.5 X 1000)=10 \mu \mathrm{g} / \mathrm{ml}$, prior to drug partitioning. The figures $1 \mathrm{a}-\mathrm{e}$ for $100 \mathrm{ml}$ of blood depict the five situations required for the demonstration of model calculations. Lowering effects on drug concentrations $\mathrm{C}_{\mathrm{p}}$ and $\mathrm{C}_{\text {ery }}$ due to $40 \%$ drug partitioning in to tissues are shown in Figure 1e.

The volumes of packed erythrocytes: plasma is 45: 55 and calculations must account for this numerical unevenness.
Figure 1a shows a theoretical situation for a $100 \mathrm{ml}$ blood sample immediately after a bolus injection of $25 \mathrm{mg}$ of drug $\mathrm{X}$ before any partitioning. The blood and plasma are fully separated. This setup provides for an unaffected initial plasma drug concentration $\mathrm{C}_{\mathrm{p}}$.

Figure $1 \mathrm{~b}$ shows the changes in Figure 1a after the drug has partitioned in to erythrocytes. The concentration of the drug in erythrocytes $\left(\mathrm{C}_{\text {ery }}\right)$ and in plasma water $\left(\mathrm{C}_{\mathrm{p}}\right)$ can be determined.

Figure 1c shows a clear $100 \mathrm{ml}$ plasma sample collected from supernatant after centrifugation, which had an initial drug concentration of $6 \mu \mathrm{g} / \mathrm{ml}$ as in Figure 1b. A fraction of drug is bound to plasma protein. The separated serum now has a lower drug concentration of $4 \mu \mathrm{g} / \mathrm{ml}$. Here serum drug concentration $\mathrm{C}_{\mathrm{s}}$ can be determined.

Figure $1 \mathrm{~d}$ is similar to figure $1 \mathrm{~b}$ but with lysed erythrocytes releasing the drug throughout the $100 \mathrm{ml}$ sample. This gives the whole blood drug concentration $C_{b}$ calculated as follows.

Total drug in Figure $1 \mathrm{~b}$ is calculated as follows. The amount of drug in plasma fraction $=6 \mu \mathrm{g} / \mathrm{ml} \times 55 \mathrm{ml}$ plasma $=$ $330 \mu \mathrm{g}$. The amount in erythrocyte fraction $=$ $4.888 \times 45=220 \mu \mathrm{g}$. Therefore the total drug in Figure 1d following erythrocyte lysis is $330+220=550 \mu \mathrm{g}$. The $550 \mu \mathrm{g}$ quantity of the drug is distributed throughout the 100 $\mathrm{ml}$ sample. Therefore the resulting $\mathrm{C}_{\mathrm{b}}$ is $550 \mu \mathrm{g} / 100 \mathrm{ml}=5.5 \mu \mathrm{g} / \mathrm{ml}$. 
Figure $1 \mathrm{e}$ is similar to Figure $1 \mathrm{~b}$ but in to tissues. assumed that $40 \%$ of the drug has diffused

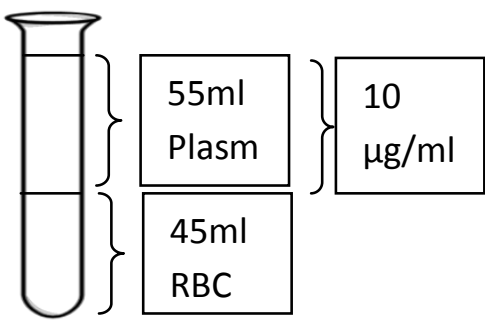

$1 \mathrm{a}$

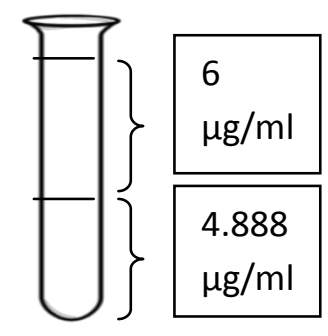

$1 b$

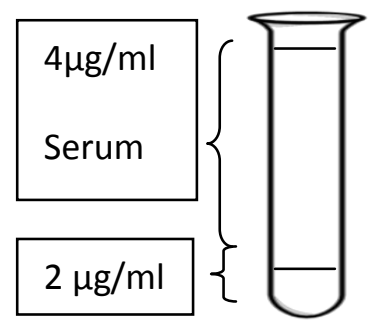

$1 \mathrm{c}$

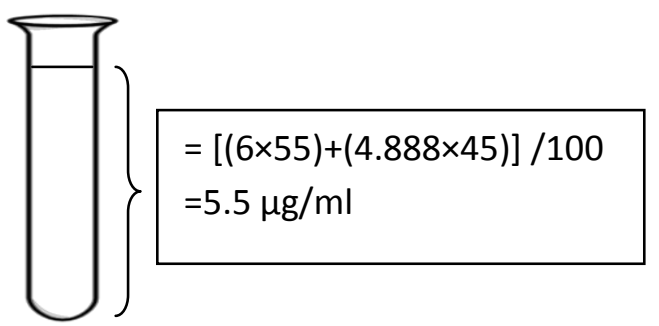

$1 d$

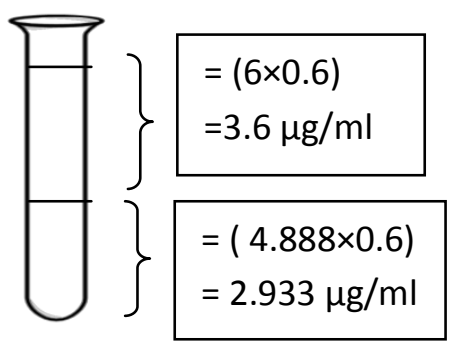

$1 \mathrm{e}$

Figure 1: Partitioning of 25mg IV bolus. 1a; Drug in plasma immediately after injection. 1b; A fraction of drug partitioned in to erythrocytes. 1c; Precipitation of plasma proteins with bound drug from plasma fraction in 1b. 1d; Lysed erythrocytes releasing drug. 1e; Drug partitioning as in $1 \mathrm{~b}$ when $40 \%$ drug has diffused in to tissues.

Demonstration of aberrations in $V_{D}$ values using model calculations:

According to Figures 1a $-\mathrm{d}$ several drug concentration factors can be identified in different samples of same blood. They are $\mathrm{C}_{\mathrm{p}} 6 \mu \mathrm{g} / \mathrm{ml}$ (Fig. 1b), $\mathrm{C}_{\text {ery }} 4.888 \mu \mathrm{g} / \mathrm{ml}$ (Fig. 1b), $\mathrm{C}_{\mathrm{s}} 4 \mu \mathrm{g} / \mathrm{ml}$ (Fig.1c), $\mathrm{C}$ protein $2 \mu \mathrm{g} / \mathrm{ml}$ (Fig.1c) and $\mathrm{C}_{\mathrm{b}} 5.5 \mu \mathrm{g} / \mathrm{ml}$ (Fig. 1d). In understanding $\mathrm{V}_{\mathrm{D}}$ studies properly blood should be considered to have several subcompartments ${ }^{6}$.

According to Figure $1 \mathrm{~b}$ applying $\mathrm{C}_{\mathrm{p}}, \mathrm{V}_{\mathrm{D}}=$ $(25 \mathrm{X} 1000) / 6=4167 \mathrm{ml}$. In Figure 1c applying $C_{s}, V_{D}=(25 X 1000) / 4=6250 \mathrm{ml}$. In Figure $1 \mathrm{~d}$ applying $\mathrm{C}_{\mathrm{b}}, \mathrm{V}_{\mathrm{D}}=(25 \mathrm{X}$ $1000) / 5.5=4545 \mathrm{ml}$. It is proposed that the correct $\mathrm{V}_{\mathrm{D}}$ is $4545 \mathrm{ml}$ based on $\mathrm{C}_{\mathrm{b}}$ in Figure $1 d$. The difference between the highest and 
the lowest $\mathrm{V}_{\mathrm{D}}$ values amount to $6250-4167$ $=2083 \mathrm{ml}$ or $2.1 \mathrm{~L}$.

\section{Theoretical demonstration of anomalies} of $C_{P}$ based $V_{D}$ determinations when $C_{e r y}$ is neglected:

An IV dose of $250 \mathrm{mg}$ results in a $100 \mu \mathrm{g} / \mathrm{ml}$ $\left(\mathrm{C}_{\mathrm{P}}\right)$ as explained earlier under subsection
'Model theoretical $\mathbf{V}_{\mathbf{D}}$.......'.Take an extreme example where $98 \mu \mathrm{g} / \mathrm{ml}$ of a drug has partitioned in to erythrocytes $\left(\mathrm{C}_{\text {ery }}\right)$ and only $2 \mu \mathrm{g} / \mathrm{ml}$ is left in plasma $\left(\mathrm{C}_{\mathrm{P}}\right)$ and also the reverse situation where $2 \mu \mathrm{g} / \mathrm{ml}$ for $\mathrm{C}_{\text {ery }}$ and $98 \mu \mathrm{g} / \mathrm{ml}$ for $C_{p}$. The $V_{D}$ calculations based on the above concentration values will be as follows.

The $V_{D}$ based on $2 \mu \mathrm{g} / \mathrm{ml}\left(C_{P}\right): V_{D}=(250 X 1000) / 2=125000 \mathrm{ml}$ or $\underline{125 \mathrm{~L}}$. (Eqn. $\left.A\right)$

The $\mathrm{V}_{\mathrm{D}}$ based on $98 \mu \mathrm{g} / \mathrm{ml}\left(\mathrm{C}_{\mathrm{P}}\right): \mathrm{V}_{\mathrm{D}}=(250 \mathrm{X} 1000) / 98=2551 \mathrm{ml} \quad$ or $2.55 \mathrm{~L}$. (Eqn. $\left.\mathrm{B}\right)$

Whole blood drug concentration $\mathrm{C}_{\mathrm{b}}$ can be calculated as shown below based on Figure 1d.

For the first set of data,

Amount of drug in plasma $=2 \mu \mathrm{g} / \mathrm{ml} \mathrm{X} 55 \mathrm{ml}=110 \mu \mathrm{g}$

Amount of drug in erythrocytes $=98 \mu \mathrm{g} / \mathrm{ml} \mathrm{X} 45 \mathrm{ml}=4410 \mu \mathrm{g}$

Total drug in $100 \mathrm{ml} \quad=4520 \mu \mathrm{g}$

Therefore $C_{b}=45.2 \mu \mathrm{g} / \mathrm{ml}$ and the $V_{D}$ based on $C_{b}=(250 X 1000) / 45.2$ or 5.531L (Eqn. C)

For the second set of reversed data:

Amount of drug in plasma $\quad=98 \mu \mathrm{g} / \mathrm{ml}$ X $55 \mathrm{ml}=5390 \mu \mathrm{g}$

Amount of drug in erythrocytes $=2 \mu \mathrm{g} / \mathrm{ml} \mathrm{X} 45 \mathrm{ml}=90 \mu \mathrm{g}$

Total drug in $100 \mathrm{ml} \quad=5480 \mu \mathrm{g}$

Therefore $C_{b}=54.8 \mu \mathrm{g} / \mathrm{ml}$ and the $\mathrm{V}_{\mathrm{D}}$ based on $\mathrm{C}_{\mathrm{b}}=(250 \mathrm{X} 1000) / 54.8$ or $4.562 \mathrm{~L}$ (Eqn. D)

When considering $40 \%$ tissue drug diffusion, the values for plasma and erythrocytes can be expressed as $\mathrm{C}_{\mathrm{p}} \times 0.6$ $(\mu \mathrm{g} / \mathrm{ml})$ and $\mathrm{C}_{\text {ery }} \times 0.6(\mu \mathrm{g} / \mathrm{ml})$ respectively (Fig.1e).

Selected standard graphs for Doxycycline, Chloramphenicol and Rifampicin are shown in Figures 2, 3 and 4. Zones of inhibition for supernatant and erythrocytes following incubation in drug solutions are shown in Figure 5. Drug concentrations partitioned in to erythrocytes and remained in the supernatant are shown in Table 1. 


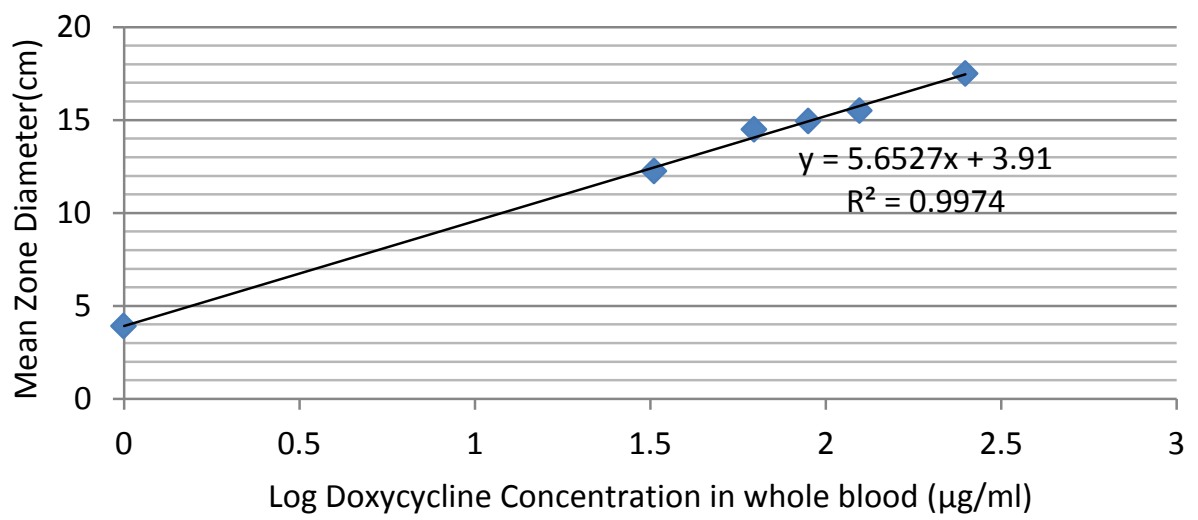

Figure 2: Standard curve for Doxycycline hydrochloride in whole blood.

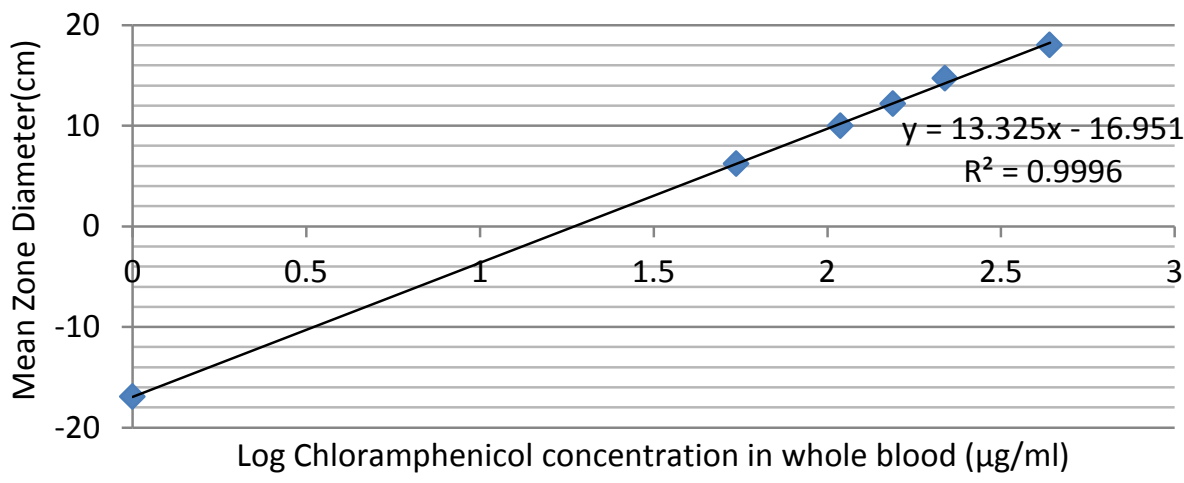

Figure 3: Standard curve for Chloramphenicol in whole blood. 


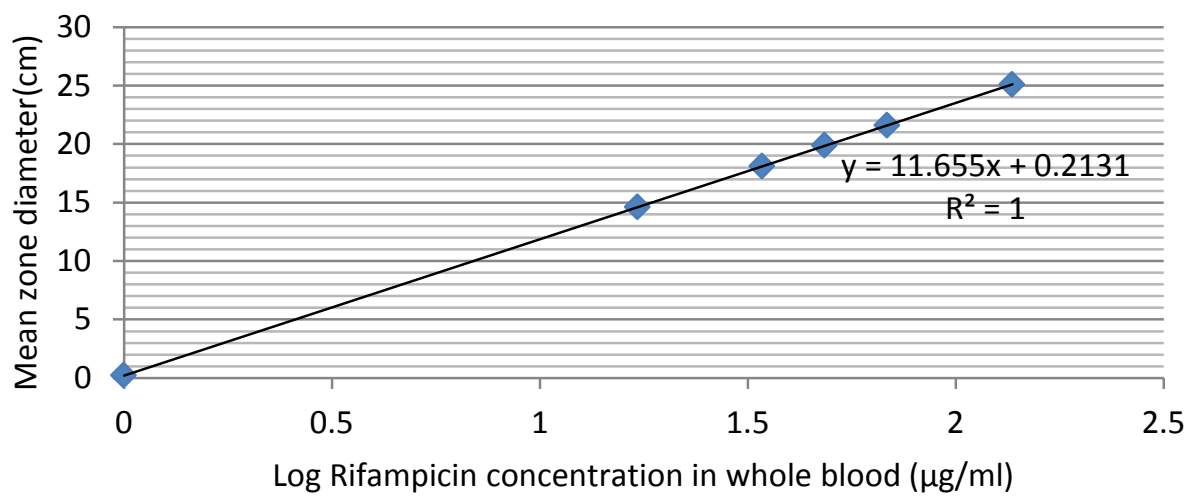

Figure 4: Standard curve for Rifampicin in whole blood

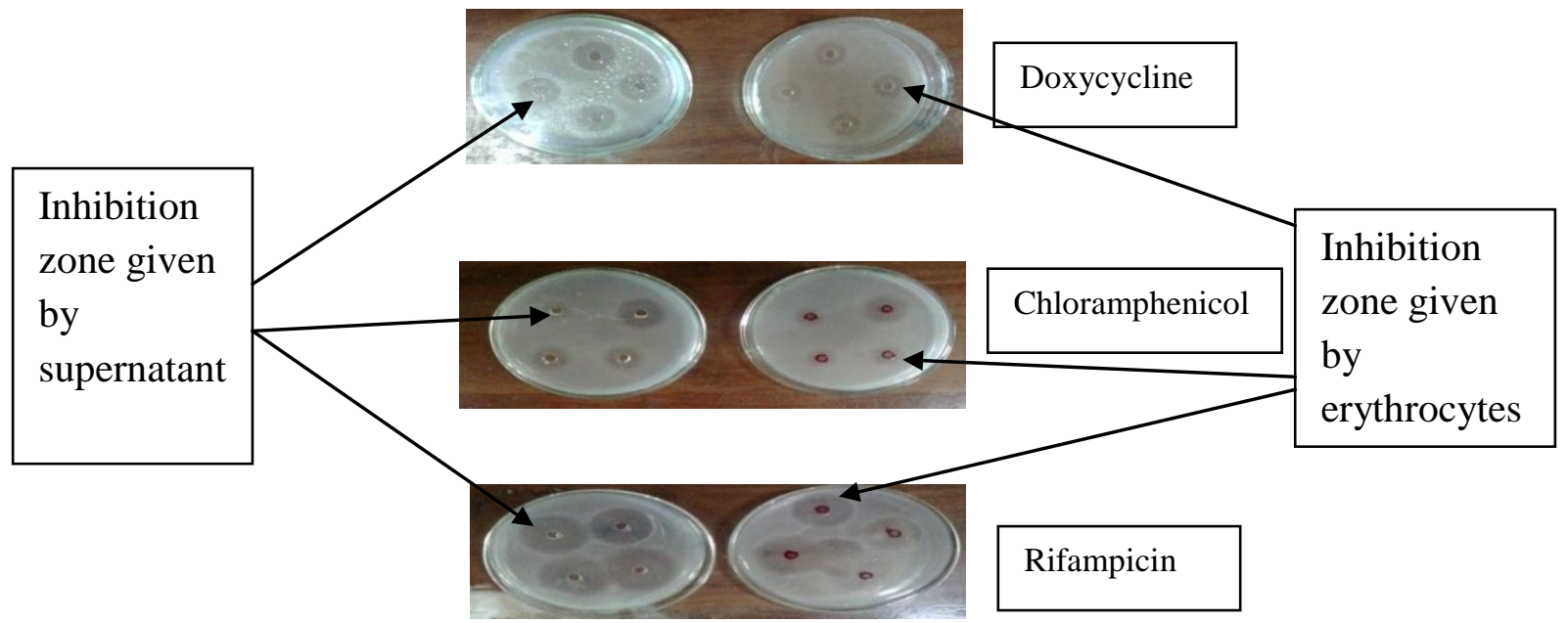

Figure 5: Inhibition zones given by erythrocytes and supernatant

\section{Results}

Calculations for percentage difference of $V_{D}$ values based on $\mathrm{C}_{\mathrm{Pw}}, \mathrm{C}_{\text {ery }}$ and $\mathrm{C}_{\mathrm{B}}$ given by the third dilution for chloramphenicol, $109.3 \mu \mathrm{g}$ $/ \mathrm{ml}$ (Table 1) based on Figure $1 \mathrm{~b}$ are shown below. Values are in same units for $40 \%$ tissue diffusion (remaining fraction 0.6) rare given in parenthesis. 
Drug in supernatant after partitioning $\left(\mathrm{C}_{\mathrm{Pw}}\right)=49.3 \mu \mathrm{g} / \mathrm{ml}(29.58)$

Drug in erythrocytes after partitioning $\left(\mathrm{C}_{\text {ery }}\right)=56.8 \mu \mathrm{g} / \mathrm{ml}(34.08)$

Drug in whole blood $\left(\mathrm{C}_{\mathrm{B}}\right) \quad=[(56.8 \times 2000)+(49.3 \times 2500)] / 4500$ $=52.63 \mu \mathrm{g} / \mathrm{ml}(31.58)$

Total amount of drug in the body $\left(\mathrm{D}_{\mathrm{B}}\right) \quad=(109.3 \times 2.5 \times 1000) \mu \mathrm{g}$ $=273250 \mu \mathrm{g}(273250$, no change $)$

$\mathrm{V}_{\mathrm{D}}$ based on plasma concentration $=\left(\mathrm{D}_{\mathrm{B}} / \mathrm{C}_{\mathrm{P}}\right)=(273250 \mu \mathrm{g} / 49.3 \mu \mathrm{g} / \mathrm{ml})=5543 \mathrm{ml}$

$\mathrm{V}_{\mathrm{D}}$ based on erythrocyte concentration $=\left(\mathrm{D}_{\mathrm{B}} / \mathrm{C}_{\text {ery }}\right)=(273250 \mu \mathrm{g} / 56.8 \mu \mathrm{g} / \mathrm{ml})=4811 \mathrm{ml}$

$\mathrm{V}_{\mathrm{D}}$ based on whole blood concentration $=\left(\mathrm{D}_{\mathrm{B}} / \mathrm{C}_{\mathrm{B}}\right)=(273250 \mu \mathrm{g} / 52.63 \mu \mathrm{g} / \mathrm{ml})=5192 \mathrm{ml}$

Maximum variance among three $\mathrm{V}_{\mathrm{Ds}} \quad=5543 \mathrm{ml}-4811 \mathrm{ml}=\underline{733 \mathrm{ml}(1020)}$

Drug in whole blood $\left(\mathrm{C}_{\mathrm{B}}\right)$ if $\mathrm{C}_{\text {ery }}$ and $\mathrm{C}_{\mathrm{P}}$ values are reversed

$$
=[(49.3 \times 2000)+(56.8 \times 2500)] / 4500 \quad=53.47 \mu \mathrm{g} / \mathrm{ml}(32.08)
$$

Table 1: Drug concentrations partitioned in to erythrocytes and remained in supernatant

\begin{tabular}{llllll}
\hline Drug & $\begin{array}{l}\text { Standard dilution } \\
\text { series }\end{array}$ & \multicolumn{2}{l}{ Plasma drug concentration } & \multicolumn{2}{l}{ Erythrocyte drug concentration } \\
& $\mu \mathrm{g} / \mathrm{ml}$ & $\mathrm{C}_{\mathrm{p}}$ & & \multicolumn{2}{l}{$\mathrm{C}_{\text {ery }}$} \\
& 250 & $\mu \mathrm{g} / \mathrm{ml}$ & $\%$ & $\mu \mathrm{g} / \mathrm{ml}$ & $\%$ \\
\hline \multirow{3}{*}{ Doxycycline } & 125 & 233.18 & 93.27 & 30.78 & 12.31 \\
& 62.5 & 114.34 & 91.47 & 14.66 & 11.73 \\
& 32.25 & 61.11 & 95.74 & 4.32 & 6.85 \\
& 437.1 & 30.03 & 94.37 & 3.5 & 10.89 \\
Chloramphenicol & 218.6 & 210.7 & 48.2 & 222.2 & 50.84 \\
& 109.3 & 109.3 & 50.0 & 113.2 & 51.78 \\
& 54.7 & 49.3 & 45.11 & 56.8 & 51.97 \\
Rifampicin & 136.9 & $\mathrm{ND}$ & $\mathrm{ND}$ & $\mathrm{ND}$ & $\mathrm{ND}$ \\
& 68.5 & 74.1 & 54.13 & 63.4 & 46.31 \\
& 34.3 & 34.3 & 50.07 & 31.2 & 45.55 \\
Oxytetracycline & 17.2 & 20.5 & 59.77 & 15.8 & 46.06 \\
Chloroquine & 50.0 & 8.1 & 47.09 & 8.4 & 48.84 \\
phosphate & 100.0 & 21.26 & 42.52 & 28.24 & 56.48 \\
\hline
\end{tabular}


$\mathrm{V}_{\mathrm{D}}$ based on whole blood concentration $=$ $\left(D_{B} / C_{B}\right)=(273250 \mu \mathrm{g} / 53.47 \mu \mathrm{g} / \mathrm{ml})=$ $5110 \mathrm{ml}$

No drastic difference in $V_{D}$ values $(5192 \mathrm{ml}$ and $5110 \mathrm{ml}$ ) even when $C_{P}$ and $C_{\text {ery }}$ values are changed.

\section{Discussion}

On an average adult blood volume of $4.5 \mathrm{~L}$ the erythrocytes occupy $45 \%$ equivalent to $2.0 \mathrm{~L}$. The drug in erythrocytes is not represented in the formula $D_{B}=V_{D}$. $C_{P}$. Most studies avoid $\mathrm{C}_{\mathrm{b}}$ determinations due to the presence of hemaglobin from lysed erythrocytes. The regular formula for volume of distribution determinations should be $V_{D}=D_{B} / C_{b}$. This formula is mainly applicable for an IV administered drug that follows one compartment model. Drug partitioned into erythrocytes practically acts like a portion that has been spilt out of the compartment model studies. In this event all the determinations that follow are flawed.

There is a problem with protein binding $\mathrm{C}_{\text {protein }}$ (Fig.1c). In the case of the anticoagulant warfarin, protein binding is as much as $99 \%$ of the drug. The $V_{D}$ values using $C_{P}$ yield unrealistic results unless the analytical procedure extracts the bound drug as well. The degree of saturation of binding sites, the intensity of binding forces, type of bonds, functional groups of amino acids involved, types of plasma proteins involved, the polarity of extracting solvent system can all affect the extraction of the drug from the protein complex as against the free drug.
Equations $\mathrm{A}$ and $\mathrm{B}$ show that although the same amount of drug remains within the vascular system a drastic difference of over 40 times in the $V_{D}$ values when $C_{P}$ values are used in the calculations. Equations $\mathrm{C}$ and $\mathrm{D}$ show that results from $\mathrm{C}_{\mathrm{b}}$ values will remain nearly equal with only about $10 \%$ difference. Under $\mathrm{C}$ and $\mathrm{D}$, the $\mathrm{C}_{\text {ery }}$ fraction which has not diffused in to tissues is accounted reflecting the amount of drug held within the vascular system.

For all intent $V_{D}$ informs us how the drug is distributed in the body. Accordingly, a drug that accumulates in tissues draw most of the drug out of vascular system leading to a low $C_{P}$ and a large $V_{D}$ as per formula $V_{D}=D_{B} /$ $\mathrm{C}_{\mathrm{b}}$. Both the fractions of drug represented in plasma $C_{P}$ and in erythrocytes $C_{r b c}$ are intravascular based. These two fractions do not account for the drug distributed in to tissues which the $V_{D}$ intends to reflect. Now a low $C_{P}$ and a large $V_{D}$ as described above will still appear to hold good even when $\mathrm{C}_{\mathrm{rbc}}$ is five times the $C_{P}$ as in the case of chloroquine infected with Plasmodia. It is a distortion of the real situation with respect to biopharmaceutical interpretation of disposition of a drug. There is not so much drug in tissues as it appears. In such a situation the use of whole blood drug concentration $C_{b}$ which is a larger value than $C_{P}$ will better reflect a comparatively lower $V_{D}$ as most of the drug is accumulated in the erythrocytes.

The accurate formula for volume of distribution determinations should be $V_{D}$ $=D_{B} / C_{b}$ in which $C_{b}$ accounts for drug in plasma, plasma protein bound drug and the 
drug in erythrocytes ${ }^{7}$. In other words all of $\mathrm{C}_{\mathrm{P}}, \mathrm{C}_{\text {protein }}$ and $\mathrm{C}_{\mathrm{rbc}}$ should be lumped together using the weighted average as their volumes are not equal.

\section{Conclusion}

The amount of drug partitioned in to erythrocytes and remained in plasma varied between large percentages as indicated in Table 1. There appear to be an increasing trend in the erythrocyte partitioning when the concentration of the drug was increased. Chloramphenicol, Rifampicin and Oxytetracycline shows significant amount of erythrocyte partitioning. It indicates a potentially deleterious effect on volume of distribution determinations if $\mathrm{C}_{\text {ery }}$ values are ignored. When $\mathrm{C}_{\mathrm{b}}$ values are used no such differences occur as demonstrated by equations $\mathrm{C}$ and $\mathrm{D}$. The determination of volume of distribution using only the plasma drug concentration could be misleading. The erythrocyte partitioning should to be taken into consideration to arrive at $\mathrm{C}_{\mathrm{b}}$ for realistic $\mathrm{V}_{\mathrm{D}}$ determinations.

\section{References}

1. Wallace SM. and Riegelman S. Uptake of acetazolamide by human erythrocytes.
Journal of Pharmaceutical Sciences. 1977;66:792-731.

2. Hinderling PH. RBC- A neglected but important compartment in pharmacokinetics. Pharmacological Reviews. 1997;49:279-95

3. Verdier F, Le B. J, Calvier F, Hatin I and Blayo MC. Chloroquine uptake by

Plasmodium falciparum infected human erythrocytes during in vitro culture and its relationship to chlorpquine resistance. Antimicrobial Agents Chemotherapy.1985;27:561-564.

4. Deshmukh PV, Badgujar PC, Gatne MM, August. In-vitro red cell partitioning of doxycycline. Indian Journal of Pharmacology. 2009;41(4):173

5. Shargel L, Wu-Pong S, Yu ABC. Applied Biopharmaceutics and Pharmacokinetics. 2004.

6. Hinderling $\mathrm{PH}$. Kinetics of partitioning and binding of digoxin and its analogues in the subcompartments of blood. 1984 73; 1042-1053

7. Rambo L, Ericsson O, Alvin G, Lindstroem B, Gustafsson LL and Sjoqvist F. Chloroquine and Desethylchloroquine in plasma, serum and whole blood. Problems in assay and handling of samples. The Drug Monitor. 1985:7; 212-215 